\title{
Mechanical and thermal characterization of compact blocks made of clayey earth with wood ashes addition
}

\author{
Gbénondé Sèna Gladys Milohin ${ }^{1,2 *}$, Sènouhoua Victor Gbaguidi ${ }^{2}$, André Donnot ${ }^{1}$, Malahimi Anjorin $^{2}$, and Riad \\ Benelmir $^{1}$ \\ ${ }^{1}$ Laboratory of Testing and Research on Wood Material (LERMAB), Faculty of Science \& Technology / University of Lorraine - \\ Bd. des Aiguillettes B.P. 70239 F-54506 Vandoeuvre-lès-Nancy cedex, France. \\ ${ }^{2}$ Laboratory of Applied Energetics and Mechanics (LEMA), Polytechnic School of Abomey-Calavi / University of Abomey- \\ Calavi, 01 BP. 2009 Cotonou (Benin).
}

\begin{abstract}
The objective of this study is to evaluate the influence of wood ashes on the mechanical and thermal characteristics of the clayey earth-ashes compound (CEAC) compressed blocks. Variable mass percentages of $0 \%$ to $60 \%$ of wood ashes were incorporated to clayey earth stabilized with $10 \%$ of cement. The physical characteristics of the clayey earth were determined according to the protocols of the french association of normalization. The manufactured blocks were subjected to mechanical tests: simple compression and tensile by bending. The thermal conductivity was then appreciated by the method of the hot strip. The blocks made with a mixture of "90\% clayey earth" and " $10 \%$ cement", usually used in construction in Benin, served as a reference material. From the results obtained, it appears that the clayey earth used is a soil A2ts: fine clayed sand in a very dry state. The results of the mechanical and thermal tests show that for an addition of wood ashes between $10 \%$ and $20 \%$ by weight, the performances of the blocks are significantly improved. The CEAC blocks formulated from $80 \%$ of the mixture " $90 \%$ of clayey earth and $10 \%$ of cement" and $20 \%$ of wood ashes can be used as building materials.
\end{abstract}

\section{Nomenclature}

F0 Control block with $0 \%$ wood ashes

F1 Block reinforced with $10 \%$ wood ashes

F2 Block reinforced with 20\% wood ashes

F3 Block reinforced with $30 \%$ wood ashes

F4 Block reinforced with $40 \%$ wood ashes

F5 Block reinforced with 50\% wood ashes

F6 Block reinforced with $60 \%$ wood ashes

$\lambda \quad$ Thermal conductivity $\left(\mathrm{W} . \mathrm{m}^{-1} \cdot \mathrm{K}^{-1}\right)$

b Width $(\mathrm{cm})$

1 Length $(\mathrm{cm})$

$\mathrm{W}_{\mathrm{L}} \quad$ Liquid limit (\%)

$\mathrm{W}_{\mathrm{P}} \quad$ Plastic limit $(\%)$

$\mathrm{I}_{\mathrm{P}} \quad$ Plastic Index (\%)

$I_{c} \quad$ Consistency Index

CBR California Bearing Ratio

\section{Introduction}

Located in southern Sahara of Africa, Benin has enormous potential in terms of eco-construction. One of the excellent features of its subsoil is its richness in rocks and minerals including limestone, marble, clay, clayey earth, sand, gravel, ornamental stones, etc. which are real potential resources for the development of building materials in the Buildings and Public Works (BPW) sector. But it is clear that this wealth, hundreds of millions of tonnes of deposits, remains unfortunately untapped or underutilized. Developed on the plateaus in Southern Benin (Kétou, Zangnanado, Abomey, Aplahoué, Porto-Novo, Allada and Bopa), the clayey earth is located between $6^{\circ} 20^{\prime}$ and $7^{\circ} 20^{\prime}$ of northern latitude then $1^{\circ} 40^{\prime}$ of east longitude and covers an area of about $10500 \mathrm{~km}^{2}$ [1], [2]. On the other hand, wood and charcoal are the main sources of energy in most

* Corresponding author: dysenan@yahoo.fr 
households despite the promotion of domestic gas. Their combustion produces ashes as residues. Ashes, often considered as waste, are not exploited. In France too, there is no clearly defined valorization of wood boiler ashes which are dumped in landfills or used in agriculture without prior feasibility studies for the majority of cases; the total tonnage of these ashes is estimated at 18000 to $37000 \mathrm{t} /$ year [3]. The control of the management of wood boiler ashes, today not optimized, and often left to the appreciation of the owners or operators, appears unavoidable for an energy having a strong asset in environmental term [3]. Reflections on the valorization of these ashes in building materials [4] are justified since the effect of fly ash in the manufacture of concrete and cement or in road works has been proven in some works [5], [6], [7]. The present study aims to assess the influence of wood ash on the mechanical strength and thermal conductivity of cement stabilized compressed clayey earth-ash compound (CEAC) blocks. The goal of this work was the valuation of clayey earth and wood ash for the development of new economic and energy-efficient building materials.

\section{Materials and methods}

\subsection{Materials}

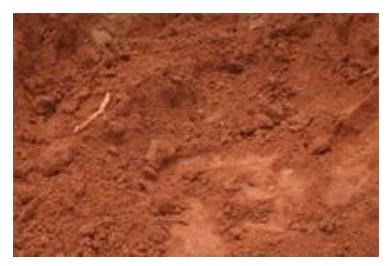

Figure 1: Clayey earth

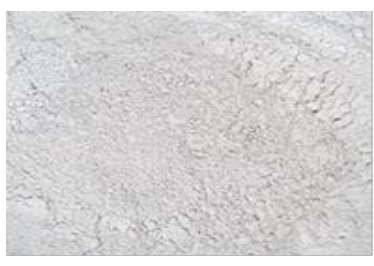

Figure 2: Wood ashes
The clayey earth used in the present study was taken at Ouedo on the plateau of Abomey-Calavi in southern Benin. After having dried the earth, it was sieved with sieves of openings of mesh $2 \mathrm{~mm}$ for the making of test pieces. The cement used for the construction of the blocks was cement from the Cement Company of Benin Lafarge (SCB Lafarge), type CEM II (CPJ 35). The wood ashes were collected in households and restorers in the town of Abomey-Calavi in Benin and sieved. The wetting water came from the drinking water supply network of the University of Abomey-Calavi.

\subsection{Characterization of the clayey earth}

In order to appreciate the nature and the condition of the clayey earth material; granulometric analyzes were carried out by sieving [8] and sedimentometry [9] after the determination of its natural water content [10]; the plasticity index was determined from the Atterberg's limits [11] and Proctor [12] and California Bearing Ratio (CBR) [13] tests were carried out on the improved clayey earth at different levels ( $0 \%$ to $60 \%)$ of ashes.

\subsection{Preparing test specimens}

Compressed earth blocks were made by substituting of varying mass proportions of wood ashes ( $0 \%$ to $60 \%)$ to a base mixture. This base was made with $10 \%$ Cement and $90 \%$ clayey earth [14] and was used here as a reference (Table 1). Test pieces of dimensions $4 \times 4 \times 16 \mathrm{~cm}^{3}$ were made then using a mechanical press designed for this purpose. The CEAC blocks thus elaborated, are designated by $\mathrm{F}$ followed a number which represents the tenth of the mass percentage of ashes introduced.

Table 1

Composition of clayey earth-ashes mixture

\begin{tabular}{cccccccc}
\hline Blocks & F0 & F1 & F2 & F3 & F4 & F5 & F6 \\
\hline $\begin{array}{c}\text { Clayey } \\
\text { earth }(\mathrm{g})\end{array}$ & 9000 & 8100 & 7200 & 6300 & 5400 & 4500 & 3600 \\
\hline $\begin{array}{c}\text { Cement } \\
(\mathrm{g})\end{array}$ & 1000 & 900 & 800 & 700 & 600 & 500 & 400 \\
\hline $\begin{array}{c}\text { Wood } \\
\text { ashes } \\
(\mathrm{g})\end{array}$ & 0 & 1000 & 2000 & 3000 & 4000 & 5000 & 6000 \\
\hline $\begin{array}{c}\text { Water } \\
(\mathrm{ml})\end{array}$ & 1085 & 1085 & 1085 & 1085 & 1085 & 1085 & 1085 \\
\hline
\end{tabular}

\subsection{Mechanical tests}

The CEAC blocks are loaded in three-point flexural test and in compression test up to the breaking. The breaking force in each case is used to determine the material strengths. The three-point flexural test is first carried out on three specimens of dimensions $4 \times 4 \times 16 \mathrm{~cm}^{3}$ in accordance with the standard NF EN 196-1 [15]. At break, two fractions of the test sample are obtained; the compression test is then carried out on a surface of $4 \times 4 \mathrm{~cm}^{2}$ of each half-sample. By denoting by $\mathbf{F}_{\mathbf{f}}$ the breaking load of the specimen in flexion, the rupture moment is:

$$
M_{f}=\frac{F_{f} l}{4}
$$

The corresponding bending stress $\mathbf{R}_{\mathbf{f}}$ is determined by:

$$
R_{f}=\frac{1.5 F_{f} l}{b^{3}}
$$

By denoting by $\mathbf{F}_{\mathbf{C}}(\mathbf{N})$ the breaking load of the specimen in compression, the compression breaking stress $\mathbf{R}_{\mathbf{c}}$ (MPa) is determined by the formula [14] :

$$
R_{c}=\frac{F_{C}}{b^{2}}
$$

\subsection{Determination of thermal conductivity}

Specimens of dimensions $(5 \times 3.5 \times 3) \mathrm{cm}^{3}$ are used for thermal tests. The measurement of the thermal conductivity has been carried out under different conditions by the hot strip method for sufficiently short times so that it can be 
assumed that the water content of the test pieces remains constant. The hot strip device used in our work consists of a $5 \mathrm{~cm}$ by $1.5 \mathrm{~cm}$ rectangular flat electric heating resistor, a temperature recorder and a stabilized power supply. The heating element is of the "minko" type of thickness $\mathrm{e}_{\mathrm{s}}=0.22$ $\mathrm{mm}$ and electrical resistance $\mathrm{Re}=43.4 \Omega$ supplied with a voltage $U=6.3 \mathrm{~V}$ with a contact resistance $R c=10^{-3} \mathrm{~m}^{2} \mathrm{KW}^{-1}$ and an inertia of the probe $(\mathrm{mc}) \mathrm{s}=10^{-3} \mathrm{JK}^{-1}$. The recording is done every second $(\mathrm{dt}=1 \mathrm{~s})$ for $180 \mathrm{~s}$. The stabilized power supply makes it possible to impose a constant flux across the heating element. Using a $0.1 \mathrm{~mm}$ diameter thermocouple attached to the center of the resistor and the recorder, the temperature rise in the center of the ribbon is noted [16].

\section{Results and discussion}

\subsection{Characterization of the clayey earth}

Clayey earth has a natural water content of $1.6 \%$. Figure 3 shows its particle size distribution. The granulometric curve is continuous and spread out. The percentage which pass through a sieve with apertures of $2 \mathrm{~mm}$ is $100 \%$. As this percentage is well above the $70 \%$ threshold set by the NFP 11-300 standard [17], the soil under study can therefore be described as sandy soil. The percentage of particles smaller than $80 \mu \mathrm{m}$ is 48.8 . This value is above the $35 \%$ threshold. The soil therefore has a similar behavior to that of its fine fraction.

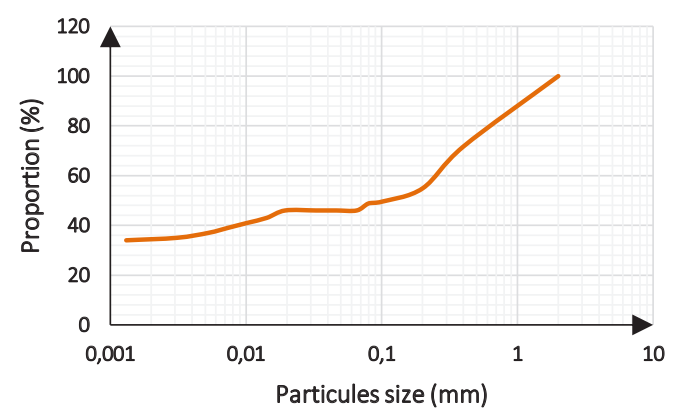

Figure 3: Granulometric curve of the clayey earth

Table 2 shows Atterberg's limits of clayey earth.

Table 2

Atterberg's limits of clayey earth.

\begin{tabular}{cccc}
\hline $\begin{array}{c}\text { Liquid } \\
\text { limit } W_{L} \\
(\%)\end{array}$ & $\begin{array}{c}\text { Plastic } \\
\text { limit } \\
\mathrm{W}_{\mathrm{P}}(\%)\end{array}$ & $\begin{array}{c}\text { Plastic } \\
\text { Index } \\
\mathrm{I}_{\mathrm{P}}(\%)\end{array}$ & $\begin{array}{c}\text { Consistency } \\
\text { Index } \\
\mathrm{I}_{\mathrm{c}}\end{array}$ \\
\hline $\mathbf{5 1}$ & $\mathbf{3 1}$ & $\mathbf{2 0}$ & $\mathbf{2 . 4 7}$ \\
\hline
\end{tabular}

Using Casagrande chart, the soil studied and represented by the point in Figure 4, according to its coordinates $\left(\mathrm{W}_{\mathrm{L}}=51 \%, \mathrm{I}_{\mathrm{P}}=20 \%\right)$ is at the limit between clays and silts. It can therefore be classified in the family of clay-loam soils with a medium plasticity. Given the value of its plasticity index $\left(\mathrm{I}_{P}=20 \%\right)$, which is between $12 \%$ and $25 \%$, the range set by the standard for moderately clayey soils, the studied earth can be described as moderately clayey soil according to standard NFP11-300 [17]. In view of the characteristics of the soil studied, the soil classification parameters according to the NFP-11-300 standard indicate that the clayey earth is a soil $\mathrm{A}_{2}$ ts: fine clay sands, silts, clays and little marl marls, arenas in a very dry state.

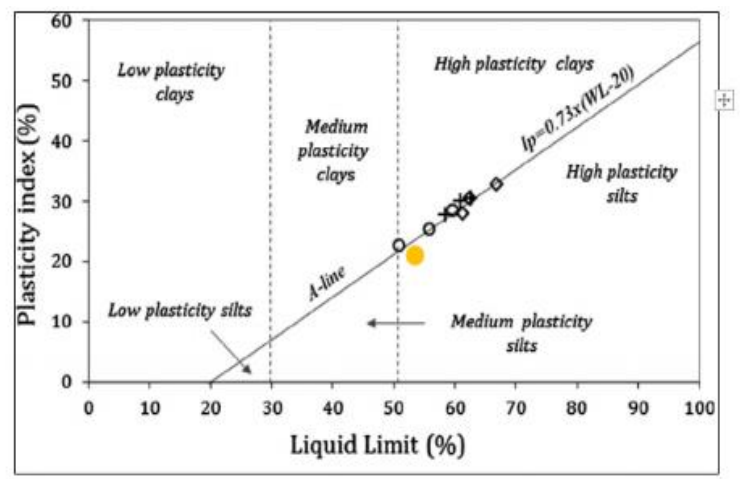

Figure 4 : Classification of the earth of bar following the Casagrande Chart

\subsection{Influence of ashes on the state parameters of the clayey earth}

The results from the Proctor test provide information on the optimal water content for a maximum dry density of the CEAC under consideration. Figure 3 shows the difference between the Proctor optimum water contents obtained and the actual water contents of the CEAC. Proctor tests are carried out on the clayey earth material at different ash contents and without the addition of cement. The CEAC blocks are stabilized at $10 \%$ cement relative to the mass of earth considered. Even when differences in formulation and compaction method are observed, the water content of the $20 \%$ ash CEAC is relatively similar. The determination of the Proctor references in particular for cement stabilized CEAC incorporating $20 \%$ ash, would make it possible to better understand the behavior of the material and its sensitivity to water. 


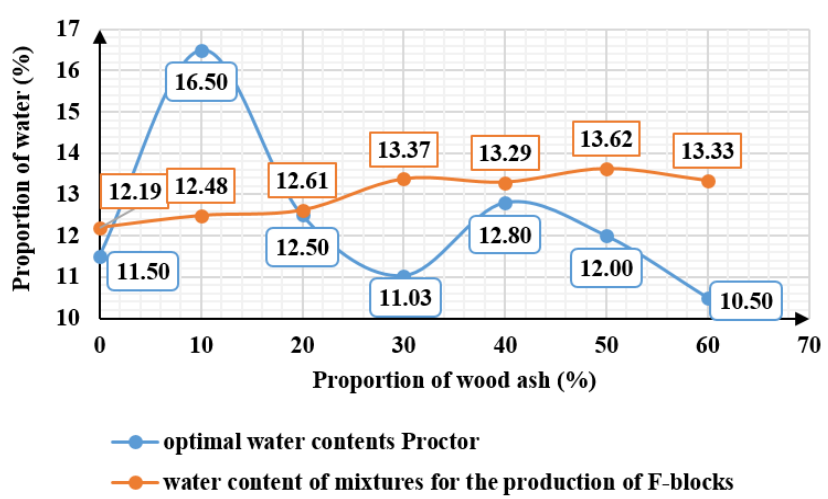

Figure 5 : Difference between optimum Proctor water contents and test $\mathrm{CEAC}$

Figure 6 presents the evolution of the CBR index as a function of the wood ash content.

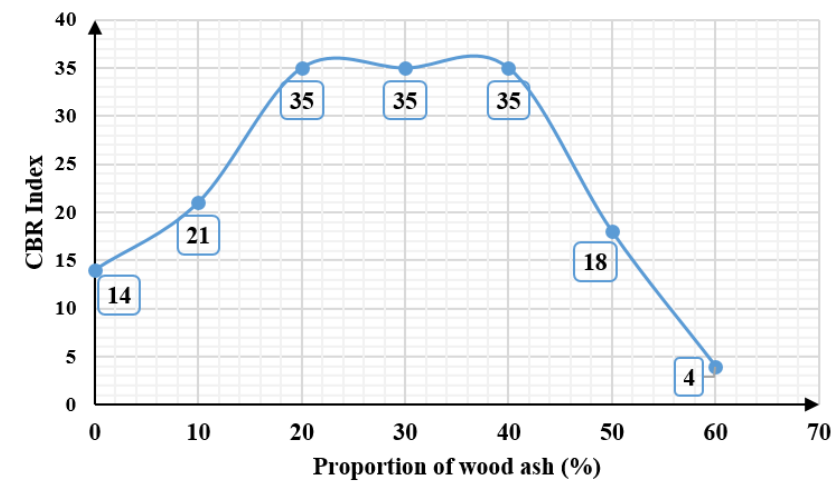

Figure 6 : Variation of the CBR index for CEAC according to the addition of ash

The values of $\mathrm{I}_{\mathrm{CBR}}$ are experiencing a remarkable increase with an ash addition of up to $20 \%$. Ashes improve the lift of the earth for a dosage between $0 \%$ and $20 \%$. Between $20 \%$ and $40 \%$, $\mathrm{I}_{\mathrm{CBR}}$ remains constant; that is to say, the increase in ash dosage no longer affects the lift of the soil which remains constant. Above $40 \%$, the index is falling rapidly. It can thus be said that ashes improve the bearing capacity of the clayey earth for a dosage of up to $40 \%$ of the soil mass considered. Above $40 \%$, it has an opposite effect on the soil.

These phenomena are explained by the fact that the additions of wood ash by integrating the texture of the clayey earth have modified its nature and especially its hydric state; remember that the material in presence is of type $\mathrm{A}_{2}$ ts. Materials in the very dry state (ts) are considered to be in a state of very low humidity and according to the NFP-11-300 standard, they no longer allow reuse under normal technical and economic conditions. At a certain dosage, the ashes modified the hydric state of the clayey earth while improving its environment and its sensitivity to the water; this improvement is maximum around $20 \%$ of addition. The knowledge of the chemical composition of the wood ash studied could help to better understand the chemical reactions that occur within the CEAC and that justify the recorded performances.

\subsection{Visual aspect of the blocks}

The color of the blocks varies according to the ash dosage (Photo 7). The higher the proportion of ash, the more whitish the cement-stabilized blocks of earth with the addition of ashes appears. However, we observe the homogeneity of the blocks in all their volume (Photo 8, Photo 9 and Photo 10).
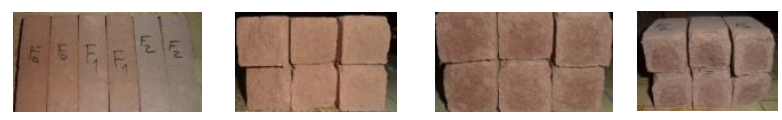

Appearance of

Figure 8:

Figure 9:

Figure 10: the CEAC Heart of the Heart of the blocks $10 \%$ Heart of the blocks blocks $0 \%$ ashes blocks $20 \%$ ashes

\subsection{Three-point flexural tensile strength}

Figure 11 presents the different results obtained for the different ash dosages at 7, 14, 21 and 28 days.

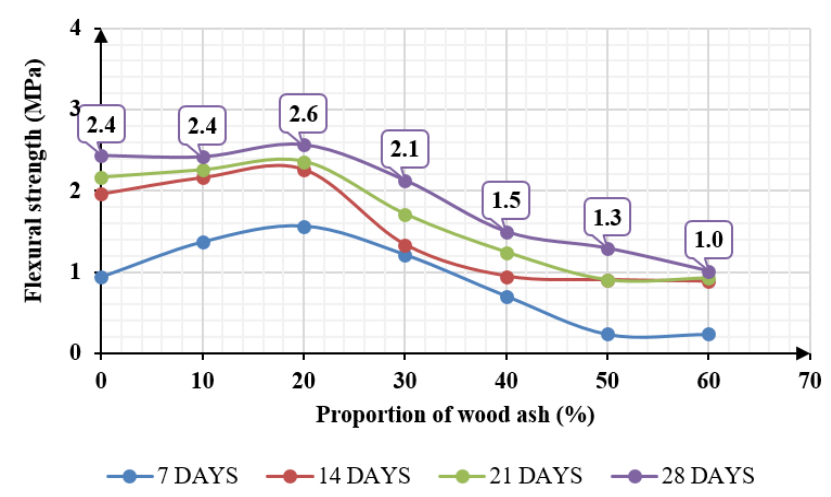

Figure 11 : Influence of ash dosage on CEAC blocks bending tensile strength

It can be seen that, for each dosage, the flexural tensile strengths increase as a function of time. With the addition of wood ash, between $0 \%$ and $20 \%$, the resistance increases as the ash dosage increases (F0, F1 and F2) with a maximum resistance at $20 \%$. Beyond $20 \%$, the resistance decreases with the added ashes.

\subsection{Resistance in compression}


Figure 12 presents the results in compression.

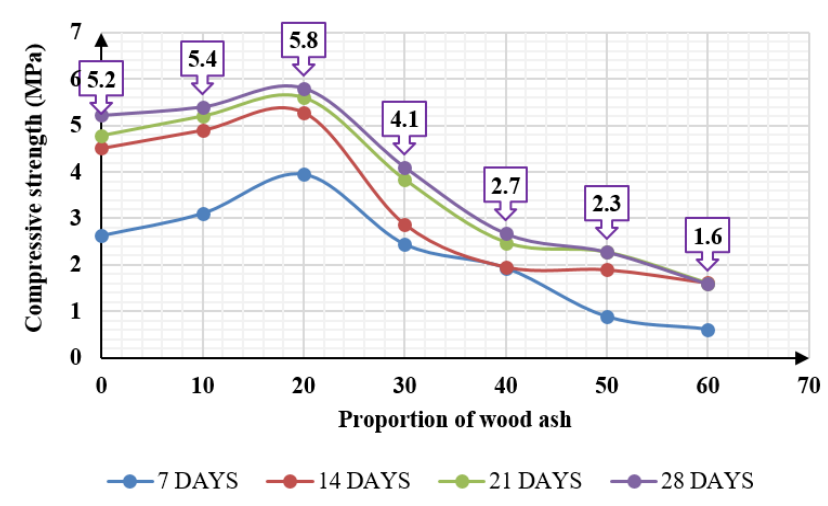

Figure 12 : Influence of ash dosing on CEAC blocks compressive strength

It can be seen that the evolution as a function of the ash dosage and the age is similar to that observed for flexural tensile strengths. We have the highest values of compressive strength for an addition of $20 \%$ of wood ashes.

\subsection{Blocks classification}

This classification is based on ARS 673-1996: Compressed Earth Blocks, Definition Standard, Classification and Designation of Masonry in Compressed Earth Blocks. So, using the aforementioned standard, manufactured blocks obtained by static compression of the earth in the wet state followed by an immediate demolding are called "Compressed Earth Blocks (CEB)" and different elements can classify them. This classification deals with the most mechanically efficient blocks "F2".

- According to the form:

The manufactured CEB are rectangular parallelepipedic solid shape, with no relief on any face, they are classified "CEB type 1".

- According to the use:

These are "CEB Ordinary (CEB O)"; Compressed Earth blocks intended to be covered by any protection.

- Depending on the field of employment:

Compared with the mechanical stresses, the CEB obtained at $20 \%$ ash dosage can be found in one or other of the following categories:

"Category 1": non-load bearing structural elements and structural elements that can withstand minor stresses by external loads.

"Category 2": structural elements that can withstand heavy loads by external loads.

Compared to the environmental demands, the CEB developed are found in the "S category" that is to say the structural elements in a dry environment without risk of humidification. They can therefore be used as interior partitions or external walls that are not exposed or protected from water attack.
Blocks F2 are therefore "CEB O 2 S" that is to say: Earth blocks intended to be covered by any protection (Ordinary) used in structural elements and can withstand significant stresses by external loads (2) in a dry environment without risk of humidification (S).

But given the composite nature of the material developed by its improvement to ashes, and lack of results on water absorption and abrasion of the material developed, the same standard recommends as a safety measure to overcome this deficiency by increasing requirements for dry and / or wet compressive strength of a category. Thus, the blocks made and characterized will be designated by "BTC O $1 \mathrm{~S}$ " that is to say the Earth blocks intended to be covered by any protection (Ordinary) used in non-structural elements and structural elements able to withstand low stresses (1) in a dry environment without risk of humidification (S).

These new materials obtained can therefore serve as filling elements in a load-bearing structure, for example a building in ground floor in structural elements carrying. However, care must be taken to protect them from the weather by using them as interior partitions or by making significant roof overhangs, protections against splashing, sufficiently high bases or drainage at the feet of walls.

\subsection{Thermal conductivity}

Figure 13 shows the thermal conductivity at 21, 28 and 45 days of CEAC blocks.

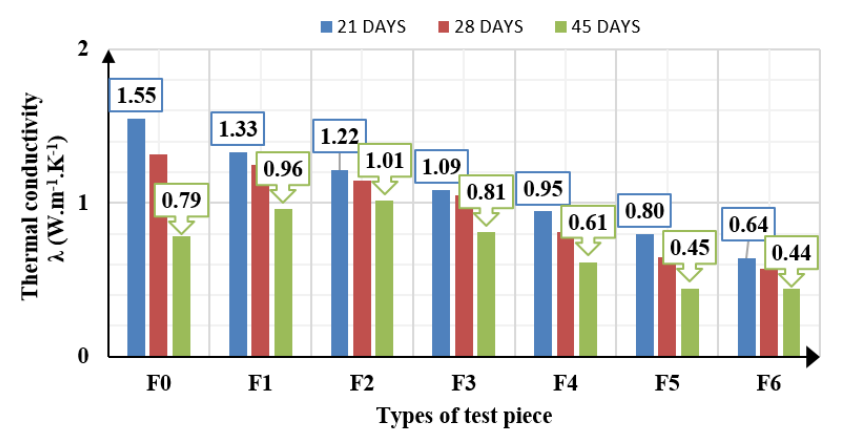

Figure 13 : Influence of ash dosage on the thermal conductivity of CEAC blocks

Whatever CEAC blocks (F0, F1, F2, F3, F4, F5 or F6), the thermal conductivity evolves in opposite direction to the age. Between 0 and $20 \%$ of ash dosage is observed at 45 days of age, an increase in thermal conductivity depending on the ash dosage and beyond $20 \%$, a drop. The thermal conductivity value $\lambda=1.01$ W. $\mathrm{m}^{-1} \cdot \mathrm{K}^{-1}$ obtained for the F2 CEAC blocks at 45 days, however, is within the recommended range $0.8 \leq \lambda \leq 1.3$ (W.m-1. $\mathrm{K}^{-1}$ ) for cement stabilized blocks [18]. 
By thus combining the thermal and mechanical results obtained on the cement stabilized CEAC blocks, it can be deduced that the CEAC blocks with the addition of $20 \%$ of ash "F2" can be used for construction elements working in compression and / or traction.

\section{Conclusions}

The purpose of this work is to value and evaluate the mechanical and thermal performance of the clayey earth under the influence of the addition of wood ash. From the characterization of the basic material used, it is clear that the clayey earth is a soil $\mathrm{A}_{2}$ ts that is to say, fine clay sand, in a very dry state. The study of the influence of ashes on the state parameters makes it possible to deduce that reactions occur within the material when ashes and cement are present; Proctor's optimum water content is not suitable for making cement stabilized compressed clayey earth-ash compound (CEAC) blocks. The study of the influence of wood ash dosage on the mechanical properties of the elaborated CEAC blocks makes it possible to retain the $20 \%$ ash "F2" dosage as ideal with the values of compressive strength and flexural tensile strength respectively of $5.8 \mathrm{MPa}$ and $2.6 \mathrm{MPa}$ higher than those of blocks "F0" (0\% ash) respectively 5.2 $\mathrm{MPa}$ and $2.4 \mathrm{MPa}$. The thermal conductivity analysis by the hot strip method revealed that the elaborate "F2" CEAC blocks have a thermal conductivity of the order of $1.01 \mathrm{~W} \cdot \mathrm{m}^{-1} \cdot \mathrm{K}^{-1}$. CEAC blocks F2 are designated "CEB O 1 S" Earth blocks intended to be covered by any protection (Ordinary) used in non-load bearing structural elements and structural elements able to withstand low stresses (1) in dry environments without risk of humidification (S) and can be used as filling elements in the supporting structures of individual houses.

\section{Acknowledgments}

This work was performed in part at the laboratory of Thermophysical Characterization of Materials and Energy Appropriation (Labo-CTMAE) at Polytechnic School University of Abomey-Calavi (BENIN), under the kind supervisions $\mathrm{Dr}$ DJOSSOU Armand A.

\section{References}

1. A. Azontonde, Dégradation et Restauration Des Terres Au Sud Du Bénin, Centre National d'Agro-Pédologie (CENAP), B.P. 988 Cotonou-Bénin.

2. A. Azontonde, Dégradation et restauration des terres de barre (sols ferrallitiques faiblement désaturés argilo-sableux) au Bénin, Cah Orstom Sér Pédol, XXVIll (2), pp. 217-226 (1993).

3. S. Bouvot and Mauduit, Etude de valorisation des cendres de chaufferies bois, TC899-011421-CL-PFLCR-rév. 5, ADEME DVNAC, Bureau d'Etudes TRIVALOR (2001).
4. ADEME, Valorisation des cendres de chaufferies bois dans les matériaux de construction, [Online] Available: http://www.ademe.fr/content/valorisationcendres-chaufferies-bois-materiaux-construction [Accessed: 23-Feb-2018].

5. A. KAROUITE, Utilisation des cendres volantes pour la prévention des désordres dus à l'alcali-réaction, Ecole HASSANIA des Travaux publics (2003).

6. P. Souchu, L'utilisation des cendres volantes dans le béton (2014) Site Doc. Lerm [Online]. Available: http://doc.lerm.fr/lutilisation-cendres-volantes-beton/ [Accessed: 23-Feb-2018].

7. J. Dailly, Valorisation de Cendre Volante de Papeterie En Techniques Routières, $\mathrm{PhD}$ Thesis, INSA de Strasbourg (2007).

8. AFNOR, NF P94-056 Sols: Reconnaissance et Essais. Analyse Granulométrique Des Sols - Méthode Par Tamisage à Sec Après Lavage (1996).

9. AFNOR, NF P94-057 Sols: Reconnaissance et Essais. Analyse Granulométrique Des Sols - Méthode Par Sédimentation (1992).

10. AFNOR, NF P94-050 Sols: Reconnaissance et Essais. Détermination de La Teneur En Eau Pondérale Des Matériaux - Méthode Par Étuvage (1995).

11. AFNOR, NF P94-051 Sols: Reconnaissance et Essais. Détermination Des Limites d'Atterberg - Limite de Liquidité à La Coupelle - Limite de Plasticité Au Rouleau (1993).

12. AFNOR, NF P94-093 Sols : Reconnaissance et Essais: Détermination Des Références de Compactage d'un Matériau Essai Proctor Normal - Essai Proctor Modifié (1999).

13. AFNOR, NF P94-078 Sols : Reconnaissance et Essais: Indice CBR Après Immersion - Indice CBR Immédiat - Indice Portant Immédiat. Mesure Sur Échantillon Compacté Dans Le Moule CBR (1997).

14. M. Anjorin, M. Toukourou, C. A. Houngan, C. Awanto, L. Madougou, Characterization of Stabilized Earth Blocks with Incorporation of Cement Expanded Polystyrene for Use in Buildings, J. Civ. Eng. Archit., 10 (1) (2016).

15. AFNOR, NF EN 196-1 Méthodes d'essai Des Ciments - Partie 1: Détermination Des Résistances Mécaniques (1995).

16. C. A. Houngan, C. Awanto, A. A. Djossou, M. Anjorin, A. Vianou, Measurement of Thermal Effusivity and Thermal Conductivity at Various Water Content for Two Tropical Wood Species, Procedia Eng., 127, pp. 48-55 (2015).

17. AFNOR, NF P11-300 Exécution Des Terrassements. Classification Des Matériaux Utilisables Dans La Construction Des Remblais et Des Couches de Forme D'infrastructures Routières (1992).

18. T.-D. Nguyen, Etude du comportement au Feu des Maçonneries de Briques en Terre Cuite: approche expérimentale et modélisation du risque d'écaillage," Université Paris-Est, Laboratoire MSME (FRE3160 CNRS) (2009). 